\title{
Prevalence of Coagulase-Positive Staphylococci (CPS) in Chicken Meat Sold in Chennai Metropolis and its Suburbs
}

\author{
P. Selvan* \\ Department of Food and Industrial Microbiology, College of Food and Dairy Technology, \\ Koduvalli, Alamathi Post, Chennai - 600 052, Tamil Nadu, India \\ *Corresponding author
}

\begin{tabular}{|l|}
\hline Ke y w o r d s \\
Coagulase Positive \\
Staphylococci, \\
Chicken meat, \\
butcher shop, \\
Chennai
\end{tabular}

\section{Keywords}

Coagulase Positive

butcher shop,

Chennai

Article Info

17 March 2019

10 April 2019

\section{A B S T R A C T}

A study was carried out to determine the prevalence of Coagulase-Positive Staphylococci (CPS) in chicken processing tools such as defeathering machine, wooden log and also chicken meat sold at butchers' shop in five different locations in and around Chennai city. A total of 150 samples were assessed and each fifty represented the processing tools and chicken meat. Mean CPS count in defeathering machine, wooden log used for fabrication and chicken meat were 3.16, 2.97 and $3.78 \mathrm{log}$ cfu/sq.in., or g of sample, respectively. One way analysis of variance to assess the effect of location on CPS count revealed that mean CPS count in defeathering machine and chicken meat samples did not statistically differed between locations whereas mean CPS count in wooden log differed significantly $(p<0.05)$ between locations. Correlation studies revealed the existence of highly significant $(p \leq 0.01)$ correlation between CPS count in chicken meat and defeathering machine and also with that of wooden log. Predictive modeling studies in chicken meat at two different static temperatures to envisage the growth kinetics of CPS during transport and at consumers' kitchen revealed that the level of $10^{6} \mathrm{cfu} / \mathrm{g}$, required to elaborate enterotoxins, would be reached when the meat is left at $29.8^{\circ} \mathrm{C}$ for approximately $10 \mathrm{hrs}$ and 30 minutes. The same level would be reached when the meat is kept at $7.5^{\circ} \mathrm{C}$ for approximately 22 days. The investigation highlighted that these organisms are very common and constitute a risk for consumers' health. Further, it became evident that the hygiene practices are not being followed at the butchers' shops. Results of predictive modeling studies showed that there is absolutely less or no risk of enterotoxin production in raw chicken meat while consider existing consumer practices.

\section{Introduction}

Chennai is the sixth most populous city in India wherein $70 \%$ of the population is nonvegetarian and consumes predominantly chicken meat. With respect to poultry processing, 'wet market' system is largely being followed in which the broiler chickens, are processed in butchers' shop adopting ritual slaughter methods and sold to the consumer as hot meat. This often lacks basic facilities, meat inspection and personnel hygiene of the butchers' involved etc., and thus adds up to the microbial load of chicken meat. Bhaisare et al., (2014) reported that poultry meats are often found contaminated 
with potentially pathogenic microorganisms. Several studies have also indicated the prevalence of drug resistant strains of $S$. aureus in foods, environment (Tambekar et al., 2011; Ruban et al., 2012; Agarwal et al., 2012), chicken meat and its products (Boer et al., 2009; Pesavento et al., 2007). Shale et al., 2005 and Kadariya et al., 2014 have reported that Staphylococcus aureus has been consistently shown to be one of the most important micro-organisms responsible for food poisoning outbreaks worldwide. Further, in a pilot study to investigate food poisoning cases in Hyderabad, Sudershan et al., (2014) pointed that Staphylococcus aureus was the etiological agent in most cases of food poisoning. Nema et al., 2007 also reported an outbreak of staphylococcal food poisoning in a social gathering after the consumption of a snack called "Bhalla" made up of potato balls fried in vegetable oil. Keeping above points in view, the present study was proposed to assess the prevalence of coagulase positive Staphylococci in chicken meat sold in Chennai Metropolis and its suburbs.

\section{Materials and Methods}

\section{Microbial analysis}

A total of 150 samples, each fifty representing, defeathering machine, wooden log and chicken meat from butchers' shops in five different locations in and around Chennai city, were aseptically collected and transported to Food and Industrial Microbiology Laboratory, College of Food and Dairy Technology at $4{ }^{\circ} \mathrm{C}$ in insulated and refrigerated container and enumerated for Coagulase Positive Staphylococci using pour plate technique described by APHA, 1984.

\section{Predictive modeling}

A predictive modeling study in chicken meat has been carried out using Combase growth model to envisage the growth kinetics of CPS at two different static temperatures $\left(29.8^{\circ} \mathrm{C}\right.$ and $\left.7.5^{\circ} \mathrm{C}\right)$. S. aureus was considered as model micro-organism. Staphylococcal counts should reach approximately $10^{6} \mathrm{cfu} / \mathrm{g}$ to produce enterotoxin (Necidová et al., 2009 and, Pelisser et al., 2009). Hence, in the present study, the time required to attain this level in chicken meat at $29.8^{\circ} \mathrm{C}$ and $7.5^{\circ} \mathrm{C}$ were also predicted.

\section{Statistical analysis}

The Analysis of Variance and Pearson correlation were carried out using SPSS statistical software.

\section{Results and Discussion}

The mean \pm SE values of CPS count in defeathering machine, wooden log and chicken meat sold at butchers' shop in five different locations in and around Chennai are presented in Table 1. The Mean CPS count in defeathering machines at different locations ranged between 2.88 and $3.62 \log _{10}$ cfu/sq.in., and the counts did not significantly varied between locations studied. Mean CPS count in wooden $\log$ from different locations ranged between 2.85 and $3.22 \log _{10} \mathrm{cfu}$ /sq.in., and the counts significantly $(\mathrm{p} \leq 0.05)$ varied between locations. Mean CPS count in wooden logs at locations II,III and IV were significantly higher $(p \leq 0.05)$ however did not significantly differ among them. Similarly, Mean CPS count in locations $\mathrm{V}$ was significantly $(\mathrm{p} \leq 0.05)$ lower however did not significantly differ from that of locations I and III. Mean CPS count in chicken meat obtained from different locations ranged between 3.70 and $3.96 \log _{10} \mathrm{cfu} / \mathrm{g}$ and the counts did not significantly varied between locations studied. The results of the correlation studies (Table 2) revealed that there is highly significant $(\mathrm{p} \leq 0.01)$ correlation between CPS counts in chicken meat, defeathering machine and wooden $\log$. 
Table.1 Mean \pm SE coagulase positive staphylococcal count in chicken processing tools and chicken meat

\begin{tabular}{|c|c|c|c|c|c|}
\hline Location & $\begin{array}{c}\text { Time of } \\
\text { collection } \\
\left(\begin{array}{c}\text { min. after } \\
\text { slaughter) }\end{array}\right.\end{array}$ & $\begin{array}{c}\text { Temp. of } \\
\text { the meat } \\
\left({ }^{\circ} \mathbf{C}\right)\end{array}$ & $\begin{array}{c}\text { Defeathering } \\
\text { machine } \\
\left(\mathbf{l o g}_{\mathbf{1 0}} \mathbf{c f u} / \mathbf{s q} . \mathbf{i}\right. \\
\mathbf{n})\end{array}$ & $\begin{array}{c}\text { Wooden } \mathbf{l o g} \\
\left(\mathbf{l o g}_{\mathbf{1 0}} \mathbf{c f u} / \mathbf{s q . i n}\right)\end{array}$ & $\begin{array}{c}\text { Chicken meat } \\
\left(\mathbf{l o g}_{\mathbf{1 0}} \mathbf{c f u} / \mathbf{s q . i n}\right)\end{array}$ \\
\hline I & 192 & $29.4 \pm 0.83^{\mathrm{ab}}$ & $3.15 \pm 0.37$ & $2.85 \pm 0.10^{\mathrm{ab}}$ & $3.77 \pm 0.10$ \\
\hline II & 150 & $31.9 \pm 0.73^{\mathrm{b}}$ & $3.62 \pm 0.14$ & $3.22 \pm 0.11^{\mathrm{c}}$ & $3.96 \pm 0.10$ \\
\hline III & 204 & $29.9 \pm 0.78^{\mathrm{ab}}$ & $3.12 \pm 0.35$ & $2.96 \pm 0.13^{\mathrm{abc}}$ & $3.76 \pm 0.07$ \\
\hline IV & 234 & $29.1 \pm 1.04^{\mathrm{a}}$ & $2.88 \pm 0.49$ & $3.11 \pm 0.12^{\mathrm{bc}}$ & $3.73 \pm 0.12$ \\
\hline $\mathbf{V}$ & 222 & $28.8 \pm 0.86^{\mathrm{a}}$ & $3.05 \pm 0.37$ & $2.74 \pm 0.07^{\mathrm{a}}$ & $3.70 \pm 0.08$ \\
\hline $\begin{array}{c}\text { Overall } \\
\text { Mean } \pm \text { SE }\end{array}$ & $\mathbf{2 0 0 . 4}$ & $\mathbf{2 9 . 8} \pm \mathbf{0 . 4 0}$ & $\mathbf{3 . 1 6} \pm \mathbf{0 . 1 6}$ & $\mathbf{2 . 9 7 \pm 0 . 0 5}$ & $\mathbf{3 . 7 8} \pm \mathbf{0 . 0 4}$ \\
\hline
\end{tabular}

Table.2 Correlations coefficient between CPS counts in chicken meat, wooden log and defeathering machine

\begin{tabular}{|c|c|c|c|c|}
\hline & & $\begin{array}{l}\text { CPS - chicken } \\
\text { meat }\end{array}$ & $\begin{array}{c}\text { CPS - wooden } \\
\log \end{array}$ & $\begin{array}{l}\text { CPS- defeathering } \\
\text { machine }\end{array}$ \\
\hline \multirow{3}{*}{$\begin{array}{l}\text { CPS - } \\
\text { chicken } \\
\text { meat }\end{array}$} & Pearson Correlation & 1 & $.525^{* *}$ & $.688 * *$ \\
\hline & Sig. (2-tailed) & & .000 & .000 \\
\hline & $\mathrm{N}$ & 50 & 50 & 50 \\
\hline
\end{tabular}

Table.3 Effect of temperature and $\mathrm{pH}$ on maximum growth rate, doubling time and time to attain CPS count of $10^{6} \mathrm{cfu} / \mathrm{g}$ of chicken meat at Consumer kitchen

\begin{tabular}{|c|c|c|c|c|c|c|c|c|}
\hline 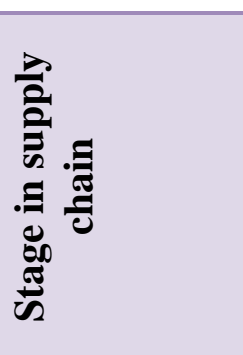 & 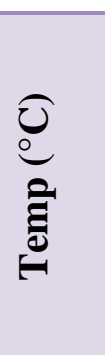 & $\begin{array}{l}\overrightarrow{\tilde{J}} \\
\stackrel{\Xi}{\Xi} \\
\stackrel{0}{0} \\
\frac{1}{2}\end{array}$ & 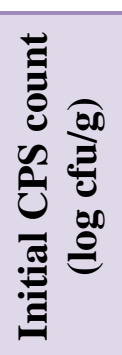 & 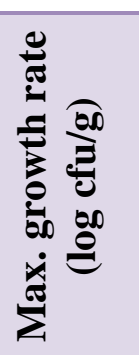 & 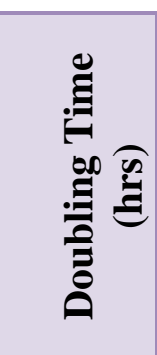 & 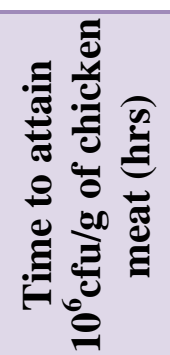 & 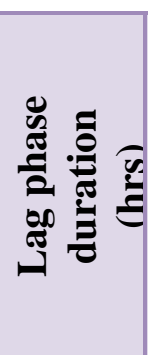 & 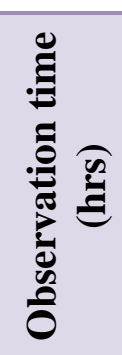 \\
\hline $\begin{array}{c}\text { At the } \\
\text { consumer } \\
\text { kitchen }\end{array}$ & 29.8 & 7.1 & 3.78 & 0.39 & 0.773 & 10.57 & 0.71 & 17.41 \\
\hline $\begin{array}{c}\text { At the } \\
\text { consumer } \\
\text { kitchen }\end{array}$ & 7.5 & 7.1 & 3.78 & 0.008 & 35.964 & 515.16 & 34.96 & 546.3 \\
\hline
\end{tabular}


Predictive modeling studies in chicken meat at two different static temperatures viz., $29.8^{\circ} \mathrm{C}$ and $7.5^{\circ} \mathrm{C}$ envisaged that the level of $10^{6} \mathrm{cfu} / \mathrm{g}$, required to elaborate enterotoxins, would be reached when the meat is left at $29.8^{\circ} \mathrm{C}$ for approximately $10 \mathrm{hrs}$ and 30 minutes. The same level would be reached when the meat is kept at $7.5^{\circ} \mathrm{C}$ for approximately 22 days. The duration of lag phase was extremely longer when the meat was expected to be stored at latter temperature compared to former. Conversely, the growth rate and doubling time were extremely higher and shorter, respectively at $29.8^{\circ} \mathrm{C}$ than at $7.5^{\circ} \mathrm{C}$ (Table 3 ).

Evaluation of meat for specific bacterial population provides information about the process, personal and environmental hygiene adopted during different unit operations of meat processing and thereby confers an opportunity to improve the processing conditions in order to ensure safe supply of meat to the intended consumers. The genus Staphylococcus is present in skin and nasal flora of humans and various animals. To date, seven species of coagulase-positive staphylococci (CPS) have been identified (Devriese et al., 2005; Freney et al., 1999). This present investigation studied the presence of CPS in chicken meat marketed in Chennai city.

The CPS was detected in almost all chicken samples examined. Badhe et al., (2013) also exactly observed similar findings while screening market chicken samples in Bangalore city, India and reported the hundred per cent prevalence of Staphylococcus aureus, in chicken meat samples obtained from outlets with minimum facilities compared to the meat samples obtained from outlets with better facilities and hygiene. Further, the results of present study are in accordance with Normanno et al., (2005) who observed the higher incidence of
CPS in foodstuffs marketed in Italy and also reported that the meat products analysed showed the highest prevalence ranging from $17.1 \%$ for the ripened meat product samples to $48.1 \%$ of the "other meat product", samples, i.e. foods prepared with fresh meat, roast beef, dishes prepared with ground meat, meat skewers, rolls, etc. However, our findings are in contrast to the results observed by Arul kumar and Saravanan (2011) who reported that out of 210 meat samples collected, $6.67 \%$ were positive for S. aureus and the colony count was $1.03 \pm 0.08 \log _{10}$ $\mathrm{cfu} / \mathrm{g}$. The lower count obtained in the latter study might be attributed to the lesser (12 h) incubation period after plating at $37^{\circ} \mathrm{C}$. Kitai et al., (2005) also observed higher prevalence $(65.8 \%)$ of $S$. aureus in 444 samples of raw chicken meat screened. In the present study, while considering the CPS counts in defeathering machine and wooden log that the CPS count in chicken meat should have been higher that the results obtained. This comparatively less count might be due to the act of skin removal in later stage of chicken processing or lower transfer rate of CPS from processing tools.

Similar to chicken meat, high prevalence of CPS was also observed in wooden $\log$ and defeathering machine used for chicken processing. Geornaras et al., (1995) also reported that in a poultry processing plant, transport cages, "rubber fingers", defeathering curtains, shackles and conveyor belts repeatedly showed aerobic plate counts in excess of $5.0 \quad \log _{10} \mathrm{CFU} / 25 \mathrm{~cm}^{2}$. Further, Listeria spp., presumptive Salmonella and Staphylococcus aureus were isolated from $27.6,51.7$ and $24.1 \%$ of all product samples, respectively, and Listeria and Staphylococcus aureus were also isolated from selected equipment surfaces. Arnold and Silver, 2000 also stated that during processing of poultry meat products, broiler carcasses come in contact with many solid surfaces. Bacteria 
from the carcasses can attach to wet equipment surfaces, form biofilms, and provide a source of cross-contamination for subsequent carcasses. Gundogan and Ataol (2013) also stated that Staphylococci may attach to the contact surfaces in both milk and meat processing industries, form biofilms and survive on them. Their attachment to food contact surfaces in food processing plants and subsequent biofilm formation pose a risk of contamination in milk and meat products. While assessing microbial status of chicken portions and portioning equipment, Holder et al., (2007) also observed that the mean $S$. aureus count on equipment, hands and utensils ranged between 1.37 and $3.53 \log _{10}$ cfu per swab. In the present study, the high prevalence of CPS in processing tools revealed that these opportunistic pathogens are very common in environment and it is very likely that the contamination of chicken meat might be occurred during processing and handling. The variation in the CPS count of wooden $\log$ at different locations might be due to the act of scrapping the surface of the former with the knife at periodical interval.

The results of correlation studies showed that these processing tools could act as a source of contamination of chicken meat. FAO (1991) also emphasized that failure to sterilize all knives and equipment regularly will result in carcass contamination.

Results of predictive modeling showed that the extremely longer duration of lag phase at $7.5^{\circ} \mathrm{C}$ and comparatively higher growth rate and shorter doubling time at $29.8^{\circ} \mathrm{C}$ would be attributed to the shorter time requirement to attain the level of $10^{6} \mathrm{cfu} / \mathrm{g}$ at $29.8^{\circ} \mathrm{C}$. ICMSF, 1996 also specified that the optimum growth temperature for $S$. aureus is between 35 and $40^{\circ} \mathrm{C}$ with growth limits at about 7 and $48^{\circ} \mathrm{C}$. Further, the commission stated that at $10^{\circ} \mathrm{C}$ there is a long lag time $(>20 \mathrm{~h})$ and when growth commences it is very slow. Similar results were also observed in the present study. Staphylococcal enterotoxins are generally produced under a more limited range of conditions compared with growth but are similarly affected by factors affecting growth (ICMSF, 1996). While consider these facts and existing consumer practices there is absolutely less or no risk of staphylococcal enterotoxin production in raw chicken meat.

Effective cleaning and sanitation of defeathering machine as well as replacement of wooden $\log$ with circular band saw will possibly improve the microbial quality of chicken meat.

Further, butchers' should be trained for hygienic slaughter and dressing of poultry as well as cleaning and sanitation of premises.

As the study reveals that the incidence of CPS is high in chicken meat, norms can be set for CPS as a process hygiene criteria in addition to Salmonella as far as developing countries are concerned.

\section{Acknowledgement}

I gratefully acknowledge the support and generosity of ITP Food Safety Core Group, Faculty of Biosciences Engineering, Gent University, Belgium, VLIR UOS and TANUVAS without which the present study could not have been completed.

\section{References}

Agarwal, A., Awasthi, V., Dua, A., Ganguly, S., Garg, V. and S.S. Marwaha, 2012. Microbiological profile of milk: impact of household practices. Ind. J. Public Health, 56(1): 88-94.

APHA, 1984. "Compendium of methods for the microbiological examination of foods", 2nd Edn., Amrican Public Health Association, Washington, DC., 


\section{USA.}

Arnold, J.W. and S. Silvers, 2000. Comparison of poultry processing equipment surfaces for susceptibility to bacterial attachment and biofilm formation. Poult Sci., 79(8):1215-21.

Arul Kumar, T.and S. Saravanan, 2011. Assessment of contamination in chicken meat by food- borne Staphylococcus aureus. Intl. J. Res. Pure and Appl. Microbiol, vol. 1:5960.

Badhe, S.R., Fairoze, M. N. and S. Sudarshan, 2013. Prevalence of Food borne pathogens in market samples of chicken meat in Bangalore, India. Ind. J. Anim. Res., 47(3): 262-264.

Bhaisare, D.B., Thyagarajan, D, Richard Churchil, R and N. Punniamurthy, 2014. Bacterial Pathogens in Chicken Meat: Review. Int. J. of Life Sciences Res., 2(3): 1-7.

Boer, E. de., Nahuis, J.T.M.Z., Wit , B., Huijsdens, X.W., Neeling, A.J.de, Bosch, T., van Oosterom, R.A.A. Vila, A. and A.E. Heuvelink, 2009. Prevalence of methicillin-resistant Staphylococcus aureus in meat. Intl. J. of Food Microbiol., 134: 52-56.

Devriese, L.A., Vancanneyt, M., Baele, M., Vaneechoutte, M., Graef, E.De., Snauwaert, C., Cleenwerck, I., Dawyndt, P., Swings, J., Decostere, A. and F. Haesebrouck, 2005. Staphylococcus pseudointermedius sp. nov., a coagulase positive species from animals. Int. J. Syst. Evol. Microbiol. 55: 1569-1573.

Freney, J., Kloos, W.E., Hajek, V. and J.A. Webster, 1999. Recommended minimal standards for description of new staphylococcal species. Int. J. Syst. Bacteriol. 49: 489-502.

Geornaras, I., Jesus, A. De., Zyl, E.V. and A.V. Holy, 1995. Microbiological survey of a South African poultry processing plant. J. of Basic Microbiol., 35(2):73-82.

Gundogan, N and O. Ataol, 2013. Biofilm, protease and lipase properties and antibiotic resistance profiles of staphylococci isolated from various foods. African J of Microbiol., Res., 7(28): 3582- 3588 .

Kadariya, J., Smith, T.C. and D. Thapaliya, 2014. Staphylococcus aureus and Staphylococcal Food-Borne Disease: An Ongoing Challenge in Public Health. BioMed Res., Intl., Vol. 2014:1- 9 .

Kitai, S., Shimizu, A., Kawano, J., Sato, E., Nakano, C., Uji, T., Kitagawa, H., Fujio, K., Matsumura, K., Yasuda, R and T. Inamoto 2005. Prevalence and Characterization of Staphylococcus aureus and Enterotoxigenic Staphylococcus aureus in Retail Raw Chicken meat throughout Japan. J. Vet. Med. Sci., 67(1): 107-110.

Necidova, L., Stastkova, Z., Pospisilova, M., Janstova, B., Strejcek, J., Duskova, M., and R. Karpiskova, 2009. Influence of soft cheese technology on the growth and enterotoxin production of Staphylococcus aureus. Czech J Food Sci 27:127-133.

Nema, V., Agrawal, R., Kamboj, D.V., Goel, A.K. and L. Singh, 2007. Isolation and characterization of heat resistant enterotoxigenic Staphylococcus aureus from a food poisoning outbreak in Indian subcontinent. Intl. J. of Food Microbiol., 117: 29-35.

Normanno, G., Firinu, A., Virgilio, S., Mula, G., Dambrosio, A., Poggiu, A., Decastelli, L., Mioni, R., Scuota, S., Bolzoni, G., Giannatale, E. Di., Salinetti, A.P., Salandra, G. La., Bartoli, M., Zuccon, F., Pirino, T., Sias, S., Parisi, A., Quaglia, N.C. and G.V. Celano, 2005. Coagulasepositive Staphylococci and 
Staphylococcus aureus in food products marketed in Italy. Intl. J. of Food Microbiol., 98:73- 79.

Pelisser, M.R., Klein, C.S., Ascoli, K.R., Zotti, T.R. and A.C.M, Arisil, 2009. Occurrence of Staphylococcus aureus and multiplex PCR detection of classic enterotoxin genes in cheese and meat products. Braz J Microbiol 40: 145148.

Pesavento, G., Ducci, B., Comodo, N and A. Lo Nostro, 2007. Antimicrobial resistance profile of Staphylococcus aureus isolated from raw meat: A research for methicillin resistant Staphylococcus aureus (MRSA). Food Control: 18: 196-200.

Ruban, S. W., Prabhu, N. K. and G. S. Naveen Kumar, 2012. Prevalence of food borne pathogens in market samples of chicken meat in Bangalore, Int. Food Res. J, 19: 1763-1765.

Shale, K., Lues, J.F.R., Venter, P and E.M. Buys, 2005. The distribution of
Staphylococcus sp. on bovine meat from abattoir deboning rooms. Food Microbiol., 22: 433-438.

Sudershan, R. V., Naveen Kumar, R., Kashinath, L., Bhaskar, $\mathrm{V}$ and $\mathrm{K}$. Polasa, 2014. Foodborne Infections and Intoxications in Hyderabad India. Epidemiology Res. Intl., 2014: 1-5.

Tambekar, D. H., Kulkarni, R.V., Shirsat, S.D. and D.G. Bhadange, 2011. Bioscience Discovery, 2(3): 350-354.

Holder, J. S., Corry, J. E. L. and M. H. Hinton, 1997. Microbial status of chicken portions and portioning equipment, British Poultry Science, 38(5): 505-511.

FAO, 1991. Animal Production and Health Paper 91. Guidelines for slaughtering, meat cutting and further processing.

ICMSF, 1996. Microorganisms in Food 5. Microbiological Specifications of Food Pathogens. Pp. 299-333.

\section{How to cite this article:}

Selvan, P. 2019. Prevalence of Coagulase-Positive Staphylococci (CPS) in Chicken Meat Sold in Chennai Metropolis and its Suburbs. Int.J.Curr.Microbiol.App.Sci. 8(04): 2513-2519. doi: https://doi.org/10.20546/ijcmas.2019.804.292 